Research article

\title{
Overexpression of the carbohydrate binding module from Solanum lycopersicum expansin 1 (Sl-EXP1) modifies tomato fruit firmness and Botrytis cinerea susceptibility
}

\author{
M.A. Perini ${ }^{\text {a, c, } 1}$, I.N. Sin ${ }^{\text {a, } 1}$, N.M. Villarreal ${ }^{\text {b }}$, M. Marina ${ }^{\text {b }}$, A.L.T. Powell ${ }^{\text {d }}$, G.A. Martínez ${ }^{\text {b. c }}$, \\ P.M. Civello a, c, * \\ a INFIVE (CONICET-UNLP), 113 n 495 - C.c 327, La Plata, 1900, Pcia Buenos Aires, Argentina \\ b IIB-INTECH (CONICET-UNSAM), Instituto de Investigaciones Biotecnológicas-Instituto Tecnológico de Chascomús, Avenida Intendente Marino km 8,2, \\ B7130IWA, Chascomús. Pcia, Buenos Aires, Argentina \\ ${ }^{\mathrm{c}}$ Facultad de Ciencias Exactas, Universidad Nacional de La Plata (UNLP), 47 y 115, 1900, La Plata, Pcia Buenos Aires, Argentina \\ d Plant Sciences Department, University of California, Davis, CA 95616, USA
}

\section{A R T I C L E I N F O}

\section{Article history:}

Received 8 June 2016

Received in revised form

29 January 2017

Accepted 31 January 2017

Available online 2 February 2017

\section{Keywords:}

CBM

Fruit softening

Cell wall

Ripening

Postharvest

\begin{abstract}
A B S T R A C T
Firmness, one of the major determinants of postharvest quality and shelf life of fruits is determined by the mechanical resistance imposed by the plant cell wall. Expansins (EXP) are involved in the nonhydrolytic metabolic disassembly of plant cell walls, particularly in processes where relaxation of the wall is necessary, such as fruit development and ripening. As many carbohydrate-associated proteins, expansins have a putative catalytic domain and a carbohydrate-binding module (CBM). Several strategies have been pursued to control the loss of fruit firmness during storage. Most of the approaches have been to suppress the expression of key enzymes involved in the cell wall metabolism, but this is the first time that a CBM was overexpressed in a fruit aimed to control cell wall degradation and fruit softening.

We report the constitutive overexpression of the CBM of Solanum lycopersicum expansin 1 (CBMSlExp1) in the cell wall of tomato plants, and its effects on plant and fruit phenotype.

Overexpression of CBM-SlExp1 increased the mechanical resistance of leaves, whereas it did not modify plant growth and general phenotype. However, transgenic plants showed delayed softening and firmer fruits. In addition, fruits were less susceptible to Botrytis cinerea infection, and the "in vitro" growth of the fungus on media containing AIR from the pericarp of transgenic fruits was lower than controls.

The possibility of overexpressing a CBM of a fruit-specific expansin to control cell wall degradation and fruit softening is discussed.
\end{abstract}

() 2017 Elsevier Masson SAS. All rights reserved.

\section{Introduction}

Fruit softening is one of the major determinants of the quality and postharvest life of fleshy fruits. Firmness of the fruit flesh is dependent on several factors, including mechanical stiffness determined by the apoplastic cell wall (Harker et al., 1997).

A network of cellulose microfibrils embedded in a complex matrix of pectins and hemicelluloses constitute the primary cell

\footnotetext{
* Corresponding author. INFIVE (CONICET-UNLP), 113 n 495 - C.c 327, La Plata, 1900, Pcia Buenos Aires, Argentina.

E-mail address: pmcivello@agro.unlp.edu.ar (P.M. Civello).

1 Authors contributed equally to this work.
}

walls of higher plants. During fruit ripening, the combined action of proteins and hydrolytic enzymes produces the reduction, solubilization and depolymerization of the polysaccharide components of the pericarp cell wall (Brummell, 2006; Taiz and Zeiger, 2006).

Expansins belong to a family of proteins without known hydrolytic activity which cause the extension of isolated cell walls, hypothetically because they break non-covalent interactions between hemicellulose and cellulose polysaccharides (McQueenMason et al., 1992; McQueen-Mason and Cosgrove, 1995). It has been postulated that expansins cause relaxation of the cell wall structure, thereby facilitating the access of other cell wall enzymes to the substrates (Cosgrove, 2000; McQueen-Mason and Cosgrove, 1995). Based on their patterns of expression and accumulation, 
expansins are involved in plant cell wall modifications (Cosgrove, 2000; Lee et al., 2001) and developmental events such as fruit ripening, when the cell size remains unchanged but wall loosening is relevant (Cosgrove, 2000; Hiwasa et al., 2003; Rose and Bennett, 1999).

Phylogenetic analysis of protein sequences has identified four expansin families, classified as $\alpha$-expansin (EXPA), $\beta$-expansin (EXPB), expansin-like A (EXLA) and expansin-like B (EXLB) (Sampedro and Cosgrove, 2005). $\alpha$-Expansin and $\beta$-expansin proteins have been demonstrated experimentally to cause cell-wall loosening (McQueen-Mason et al., 1992), and the others were identified as expansins because of sequence homology.

In tomato, strawberry, peach, pear and other fleshy fruits, the expression patterns of $\alpha$-expansin differed between cultivars with contrasting firmness (Brummell et al., 1999; Dotto et al., 2006; Harrison et al., 2001; Hayama et al., 2003; Hiwasa et al., 2003). Analysis in different plant tissues indicated that some expansins are expressed specifically in fruit, while expression of others is detected also in vegetative tissues. Rose et al. (1997) identified a fruitspecific expansin protein in tomato, Solanum lycopersicum Expansin 1 (Sl-EXP1), whose expression increases during ripening.

It has been reported that the suppression of Sl-EXP1 expression in tomato rendered firmer fruit than azygous controls throughout ripening, and that fruit overexpressing the Sl-EXP1 protein were significantly softer (Brummell et al., 1999). In addition, the simultaneous suppression of Sl-EXP1 and Sl-PG (polygalacturonase) in fruit reduced susceptibility to $B$. cinerea (Cantu et al., 2008).

A common characteristic of the structure of most of proteins involved in cell wall degradation is their modular organization. Typically, the proteins include a characteristic enzyme catalytic domain and one or more carbohydrate-binding modules (CBM), linked by an unstructured chain (Shoseyov et al., 2006). A CBM is defined as a contiguous amino acid sequence within an enzyme with activity on carbohydrates, predicted folding arrangements and the ability to bind to the carbohydrate substrate (Coutinho and Henrissat, 1999). In plants, the presence of putative CBMs has been reported in endoglucanases (Levy and Shoseyov, 2002), $\alpha$-Larabinofuranosidases (Sin et al., 2016) and expansins (Yennawar et al., 2006).

The CBM of strawberry expansin 2 (CBM-FaEXP2) has been overexpressed in E. coli and the protein was used for binding assays with different cell wall substrates. Data indicated that, in vitro, the protein binds mainly to microcrystalline cellulose, but also to oat xylan and citrus pectins (Nardi et al., 2013). CBMs from different sources were overexpressed in plant systems, and modifications of plant phenotypes were observed (Obembe et al., 2007a; SafraDassa et al., 2006). The overexpression of the CBM of strawberry expansin 2 (CBM-FaEXP2) in A. thaliana modified the plant growth as well as cell wall structure and composition. The transgenic plants had a higher amount of cell wall, mainly pectins, and lower expression of enzymes and genes related to cell wall degradation (Nardi et al., 2015).

The goal of the present work was to develop a strategy to control fruit softening by overexpressing just the CBM of the Sl-EXP1 protein in the cell wall, and to determine the outcome for plant and fruit phenotypes using tomato plant as model. Our hypothesis is that CBM overexpression would reduce the degradation of the fruit cell wall and, therefore, overall fruit softening and susceptibility to fungal infections.

\section{Methods}

\subsection{CBM-SIEXP1 cloning and plasmid construction}

The construct designed to drive the overexpression of CBM-
SIEXP1 protein in tomato cell wall followed the strategy described in Nardi et al. (2015). SignalP 4.0 online software (http:// www.cbs.dtu.dk/services/SignalP/; (Petersen et al., 2011)) and the ProSite database (http://prosite.expasy.org/; (Sigrist et al., 2013)) were used to identify and delimit the Signal Peptide (SP) and conserved domains present in SIEXP1 protein, respectively.

The sequence encoding the SP was fused to the sequence encoding the carbohydrate binding module (CBM) in two separate PCR reactions (PCR1 and PCR2) using specific primers and a plasmid containing the full length SIEXP1 cDNA (Accession number: NM_001247029.2; (Rose et al., 1997)) as template. Then, GateWay ${ }^{\circledR}$ recombination system was used to generate Entry and Expression clones using PCR2 product and standard BP and LR clonase reactions with pDONR221 (Invitrogen ${ }^{\mathrm{TM}}$ ) and pK7WG2D.1 (Karimi et al., 2002) plasmids, respectively. The vector pK7WG2D.1 has kanamycin and GFP selectable marker genes and a Cauliflower Mosaic Virus promoter (P35S-CaMV) to drive a constitutive expression of the gene of interest (GOI).

Primers used in PCR1: Forward Primer 1F, chimeric primer containing attb1 recombination site sequence (lower case) and 22 nucleotides complementary to the signal peptide (in capital letters): 5'-ggggacaagtttgtacaaaaaagcaggctta ATGGGTATCATAATTTTC ATCC-3'; Reverse Primer 1R, chimeric primer containing sequence complementary to the SP and 21 nucleotides complementary to the $5^{\prime}$ end of the CBM (underlined): 5'-TCCATTGA TGGTAAATCTGATTCTTCCTTCAACAATGTT GAA-3'. PCR1 product was purified using the GE Health Care PCR product purification kit and further used in the second PCR (PCR2) as forward primer.

Primers used in PCR2: Forward Primer 2F, PCR1 amplification product: 5'-ggggacaagtttgtacaaaaaagcaggcttaATGGGTATCATAATTTTCATCCTTGTTCTTCTTTTTGTAGACTCATGTTTCAACATTGTTGAAGGAAGAATCAGATTTACCATCAATGGA-3'; Reverse Primer 2R, chimeric primer containing attb2 recombination site sequence (lower case), a stop codon (in bold) and 22 nucleotides complementary to the $3^{\prime}$ end of the CBM sequence: $5^{\prime}$-ggggaccactttgtacaagaaagctgggta TTATATTTTGAAATTCTTTCCGATG-3'.

\subsection{Plant transformation}

Solanum lycopersicum (cultivar Ailsa Craig) plants were transformed, at the Ralph M. Parsons UCDavis Plant Transformation Facility, with the construct described above to overexpress the CBM-SIEXP1 protein. Agrobacterium tumefaciens strain GV3101 harboring the expression clone was used to infect leaf explants, and transgenic plants were obtained by in-vitro tissue culture followed by plant regeneration.

\subsection{RNA extraction and RT-PCR}

Fruit at breaker $(\mathrm{Br})$ stage were dissected to isolate the pericarps which were frozen in liquid nitrogen and stored at $-80^{\circ} \mathrm{C}$ until use. Fruit RNA was extracted using TRI Reagent ${ }^{\circledR}$, RNA Isolation Reagent $\left(\right.$ SIGMA-ALDRICH $\left.{ }^{\circledR}\right)$ following the manufacturer specifications with minor modifications. After isopropanol RNA precipitation, pellets were washed with $70 \% \mathrm{v} / \mathrm{v}$ ethanol and re-suspended in $\mathrm{mqH}_{2} \mathrm{O}$ prior a precipitation step with $3 \mathrm{M}$ sodium acetate at $-20^{\circ} \mathrm{C}$ for $1 \mathrm{~h}$. Samples were then centrifuged at $10,000 \mathrm{~g}$ for $20 \mathrm{~min}$ at $4{ }^{\circ} \mathrm{C}$, washed again with $70 \% \mathrm{v} / \mathrm{v}$ ethanol and finally re-suspended in $\mathrm{mqH}_{2} \mathrm{O}$. Each RNA sample $(6 \mu \mathrm{g})$ was treated with RNAse free RQ1DNAse (Promega), according to the manufacturer's specification, and further purified by a chlorophorm:1-octanol (24:1) extraction followed by precipitation step with $3 \mathrm{M}$ sodium acetate at $-20^{\circ} \mathrm{C}$ for $1 \mathrm{~h}$. Purified RNA was used for cDNA synthesis using MML-V reverse transcriptase (Promega) and random hexamers (Promega). The cDNA was used as template for end point PCR assays 
for transgenic plants selection, using a specific primers set for the Elongation Factor 1-alpha (Solyc06g005060) as a reference control (SIEF1a-forward: 5'-TCCAAAGATGGTCAGACCCGTGAA-3'; SIEF1areverse 5'-ATACCTAGCCTTGGAGTACTTGGG-3'; (Pombo et al., 2014)) and a specific primers set for the P35S-CBM-SIEXP1 construct [P35S-CBM-Sl-EXP1-forward: 5'-GCGGCCGCACTAGTGATA-3' (primer was designed on $5^{\prime}$ UTR of the P35S cDNA sequence); P35S-CBM-Sl-EXP1-reverse: rev 5'-TGCACCTGCTACATTCGTGA-3']. These primers sets were used to determine the presence of the transgene and then to classify the plants into azygous or CBM-SIEXP1 overexpressors (transgenic) categories.

\subsection{Plant growth conditions}

Tomato plants were grown in a greenhouse under natural light conditions in La Plata (Buenos Aires, Argentina) in $10 \mathrm{~L}$ pots with soil:perlite (3:1). The temperature was monitored and controlled between 16 and $27^{\circ} \mathrm{C}$.

\subsection{Plant phenotypical characterization}

The phenotypical characterization was done on 5 WT, 7 azygous and 17 transgenic plants, except for experiments with Botrytis. In this case, $1 \mathrm{WT}, 1$ azygous (C22-P4), and 6 transgenic plants (C22P2; C22-P5; C73-P4; C93-P3; C103-P2; C103-P3) were used to perform the assays.

\subsubsection{Plant height and number of flowers}

The height, number of flower clusters and number of flowers per cluster were measured 40 and $60 \mathrm{~d}$ post germination in transgenic, azygous and WT plants. The plant height was measured from the base to the petiole of the last expanded leaf. Only fully developed clusters and flowers were counted.

\subsubsection{Foliar area and chlorophyll content of leaves}

The chlorophyll contents of the 4th and 5th compound leaves, counting from the base, of transgenic, azygous and WT plants were estimated with a non-destructive chlorophyll meter (SPAD 502, Minolta, Japan), 40 and $60 \mathrm{~d}$ post germination. Five measurements were performed along each assayed compound leaf from each plant.

Pictures of the 4th and 5th compound leaves of each transgenic, azygous and WT plants after $40 \mathrm{~d}$ post germination were taken and analyzed using ImageJ Software (Schneider et al., 2012) to calculate foliar area.

\subsubsection{Mechanical properties of S. lycopersicum compound leaves}

An extension assay of leaves was performed using the Texture Analyzer equipment in tension mode, fitted with miniature tensile grips (TA.XTplus, Stable Micro Systems Texture Technologies ${ }^{\circledR}$, Scarsdale, NY). Two sections parallel to the longest axis of the terminal leaflet $(1 \mathrm{~cm} \times 2 \mathrm{~cm})$ were excised, excluding the central vein. The extension test was performed at a constant speed of $0.1 \mathrm{~mm} \mathrm{~s}^{-1}$ until breakage, and the applied force ( $\mathrm{gr}$ ) and the tissue extension were recorded. The force ( $g r)$ necessary to break the section of the terminal leaflet was determined twice over 5 leaves per plant and labeled as breaking force.

A leaf penetration assay also was performed using the Texture Analyzer equipment in compression mode, fitted with an ad-hoc $1 \mathrm{~mm}$ diameter cylinder probe. The assay consisted in penetrating the terminal leaflet four times on the lamella at different zones distanced $1 \mathrm{~cm}$ from the central vein. The compression test was performed at a constant speed of $0.1 \mathrm{~mm} \mathrm{~s}^{-1}$ until penetration, and the force (gr) necessary to penetrate the tissue was determined (labeled as penetration force). Tests were done by quadruplicate per terminal leaflet and five leaves per each plant were assayed.

\subsection{Fruit phenotypical characterization}

Three independent harvests of fruit were carried out in June, August and October. Fruit were harvested mature green, and stored at $22{ }^{\circ} \mathrm{C}$ in the dark to ripen. The ripening progress was monitored using firmness, color and weight loss measurements. These parameters were obtained immediately after harvest (MG), when fruit achieved Breaker stage (Br), and then every $2 \mathrm{~d}$ for a total of $6 \mathrm{~d}$ $(\mathrm{Br}+2, \mathrm{Br}+4$ and $\mathrm{Br}+6)$.

\subsubsection{Fruit firmness}

Fruit firmness was evaluated measuring the maximum force (gr) reached when fruit were compressed to cause a $0.5 \mathrm{~mm}$ deformation with a $25 \mathrm{~mm}$ diameter cylinder Perspex probe (code: $\mathrm{P} / 25 \mathrm{P}$ ) fitted in a Texture Analyzer device (TA.XTplus, Stable Micro Systems Texture Technologies ${ }^{\circledR}$, Scarsdale, NY). The following settings were used: load cell PL/CEL/30; test mode: Compress; pre-test speed: $2 \mathrm{~mm} \mathrm{seg}^{-1}$; post-test speed: $10 \mathrm{~mm} \mathrm{seg}^{-1}$. Fruit were measured twice on opposite sides of the central equatorial zone. Between 4 and 8 fruit were used per each transgenic and azygous plants, and 20 fruit for WT. Data were acquired using the Exponent Lite Analysis Software ${ }^{\circledR}$ provided with the equipment, at an acquisition rate of 200 points per second.

\subsubsection{Surface color}

Fruit surface color was evaluated with a Chroma Meter (CR300, Minolta, Osaka, Japan), measuring the parameters $\mathrm{L}^{*}, \mathrm{a}^{*}$ and $\mathrm{b}^{*}$, and calculating the hue angle $\left(\mathrm{HUE}^{\circ}\right)$ using the following formulas: $\mathrm{HUE}^{\circ}=\arctan (\mathrm{b} / \mathrm{a})$ when $\mathrm{a}>0$ and $\mathrm{b}>0 ; \mathrm{HUE}^{\circ}=180^{\circ}-\arctan (\mathrm{b} / \mathrm{a})$ when $\mathrm{a}<0$ and $\mathrm{b}>0$. Between 4 and 8 fruits were used per each transgenic or azygous plants and 20 fruits for the WT. Three measurements were performed on each assayed fruit.

\subsubsection{Weight loss}

Fruit were harvested at MG stage, the initial weight was recorded and then fruit were loosely covered with a commercial PVC film and maintained at $22{ }^{\circ} \mathrm{C}$ in the dark. The same fruit were then weighted every $2 \mathrm{~d}$ for a total of $14 \mathrm{~d}$, and weight loss was calculated as the percentage of the initial value. Between 4 and 8 fruit from each transgenic and azygous plants and 20 fruit from WT were assayed.

\subsection{Botrytis cinerea infection and growth rate analysis}

The study was done on fruit from selected plants: WT, azygous (C22-P4), and transgenics (C22-P2; C22-P5; C73-P4; C93-P3; C103P2; C103-P3).

Botrytis cinerea strain B05.10 (IIB-INTECH Fungal Culture Collection IFCC 458/02) was used in all the experiments. The strain was routinely maintained in potato-dextrose agar slants at $4{ }^{\circ} \mathrm{C}$. Prior to inoculation, mycelium was grown in solid Czapek-Dox medium (50 g glucose, $2 \mathrm{~g} \mathrm{NaNO}_{3}, 1 \mathrm{~g} \mathrm{KH}_{2} \mathrm{PO}_{4}, 0.5 \mathrm{~g}$ $\mathrm{MgSO}_{4} \cdot 7 \mathrm{H}_{2} \mathrm{O}, 0.5 \mathrm{~g} \mathrm{KCl}, 0.05 \mathrm{~g} \mathrm{FeSO}_{4} \cdot 7 \mathrm{H}_{2} \mathrm{O}, 20 \mathrm{~g}$ agar, $\mathrm{pH}=5.5-6.0$ ) at $24{ }^{\circ} \mathrm{C}$.

In vivo assays: Plates were kept from 7 to $10 \mathrm{~d}$ in darkness at room temperature for sporulation. For susceptibility assays, conidia were harvested with sterile water containing $0.02 \%$ (v/v) Tween-20 and then filtered and conidia counted with a hemocytometer. The inoculum concentration was adjusted to $2 \times 10^{4}$ conidia per $\mathrm{mL}$ with PDB medium, supplemented with $10 \mathrm{mM}$ sucrose and $10 \mathrm{mM}$ $\mathrm{KH}_{2} \mathrm{PO}_{4}$. Conidia were incubated for $2-3 \mathrm{~h}$ at room temperature without shaking prior to inoculations (Flors et al., 2007). For inoculation, four $10 \mu \mathrm{L}$ droplets were placed on the unwounded 
upper surface of each fruit. Three to six tomato fruit at mature green (MG), light red (LR) and ripe red (RR) ripening stage from each WT, azygous and transgenic plant were used. Fruit were placed in a growth chamber at $22{ }^{\circ} \mathrm{C}$ in darkness, and after $1,2,4$ and $7 \mathrm{~d}$ post inoculation they were observed, photographed with a digital camera and lesions were evaluated as follows: ( -$)$, no infection symptoms; $( \pm)$, incipient lesion on inoculation zone; $(+)$, humid lesion on inoculation zone; $(++)$, humid lesion beyond the inoculation zone and putrefaction symptoms.

In vitro assays: Cell wall polysaccharides were extracted as Alcohol Insoluble Residues (AIRs) according to D'Amour et al. (1993) with slight modifications. Tomato fruit were cut apart and outer skin (exocarp) as well as endocarp was removed likewise, only mesocarp was frozen in liquid nitrogen and stored at $-20^{\circ} \mathrm{C}$ until used. Five grams of frozen fruit at the Light Red stage (LR) were homogenized in a mixer with $20 \mathrm{~mL}$ of cooled absolute ethanol and then refluxed in boiling water during $30 \mathrm{~min}$. Once homogenates reached room temperature, they were vacuum filtered and the residue was washed three times with $15 \mathrm{~mL}$ of absolute ethanol. After this, the residue was dried overnight at $37^{\circ} \mathrm{C}$ and weighed to evaluate AIR amount. A preliminary assay was done to optimize the amount of AIR to be added for pathogen optimal growth. For this assay, a $4 \mathrm{~mm}^{2}$ agar plug was transferred from the edge of a 5-day-old actively growing culture of $B$. cinerea to the solidified plates with agar $0.8 \%(\mathrm{w} / \mathrm{v})$ and $0.02,0.1,0.2$ or $1 \mathrm{mg} \mathrm{mL} \mathrm{m}^{-1}$ of AIRs from azygous tomato fruit. Plates were then cultivated at $24^{\circ} \mathrm{C}$, and the surface area of fungus growth on the plate was measured after 24, 48 and $72 \mathrm{~h}$. Further comparisons were done using a similar methodology as described above, but using $0.1 \mathrm{mg} \mathrm{mL}^{-1}$ of AIRs from WT, azygous and transgenic tomato fruit. Three independent AIR extractions were used for each plant genotype and three technical replicates of each biological sample were made. The surface areas of the $B$. cinerea mycelium growth on the plates were measured using the Image-Pro ${ }^{\circledR}$ Plus software (Media Cybernetics Inc., San Diego, CA).

A parallel assay to determinate the starch content was performed. The starch was extracted from AIR using dimethyl sulfoxide (DMSO) according to Carpita and Kanabus (1987), with some modifications. Once extracted, $0.1 \mathrm{~mL}$ of $1 / 10$ diluted starch extract was mixed with $1 \mathrm{~mL}$ of $0.2 \%(\mathrm{w} / \mathrm{v})$ anthrone in $72 \%(\mathrm{v} / \mathrm{v})$ sulfuric acid. The mixture was incubated at $100{ }^{\circ} \mathrm{C}$ for $10 \mathrm{~min}$, cooled in a water bath at room temperature, and the starch content was measured spectrophotometrically at $620 \mathrm{~nm}$, using variable amounts of $0.04 \%(\mathrm{w} / \mathrm{v})$ glucose as standards. Results were expressed as mg of glucose per $100 \mathrm{mg}$ of AIR. Twenty-five mg of soluble starch $(\mathrm{C}+1)$ as well $12.5 \mathrm{mg}$ of soluble starch $+12.5 \mathrm{mg}$ of AIR from WT fruit $(C+2)$, were used as positive controls.

\subsection{Statistical analysis}

Data for plant phenotyphical characterization, postharvest assays and $B$. cinerea assays were analyzed by ANOVA and means were compared by Tukey tests $(p<0.05)$.

\section{Results}

\subsection{Molecular cloning and plant transformation}

Bioinformatics analysis of the endogenous SIEXP1 using SignalP 4.0 and the ProSite database revealed that SIEXP1 protein has the classical structure of plant expansins (Cosgrove, 2000; Sampedro et al., 2006). The protein has a signal peptide (SP) at the protein $\mathrm{N}$-terminus that directs the protein expression to the apoplast (first 23 amino acid residues), a putative expansin catalytic domain (42-167 amino acid residues), and a CBM at the C-terminus (177-256 amino acid residues). The nucleotide sequences of these elements were delimited in the SIEXP1 CDNA and used in the design of primers to generate the plant transformation construct. A schematic representation of the endogenous SIEXP1 gene and the recombinant CBM-SIEXP1 gene is shown in Fig. 1, along with the annealing position of the primers used in engineering the construct.

An alignment using Clustal Omega software (Sievers et al., 2011) between SIEXP1 (tomato) and FaEXP2 (strawberry) revealed that these predicted mature expansin proteins were highly conserved with an average sequence identity of approximately $70 \%$ while the identity of the CBM-SIEXP1 and CBM-FaEXP2 motif was more divergent (66\% identity) (Supp. Fig. 1).

An expression clone was designed for the constitutive overexpression of a recombinant CBM-SIEXP1 protein in Solanum lycopersicum (cv. Ailsa Craig) cell wall following the cloning strategy described in section 2.1. SlEXP1 SP, for cell wall targeting, was fused to its CBM (eliminating the expansin catalytic domain) and recombined into a binary vector, which was then used for Agrobacterium tumefaciens (strain GV3101) mediated plant transformation. The vector pK7WG2D was chosen because it contains
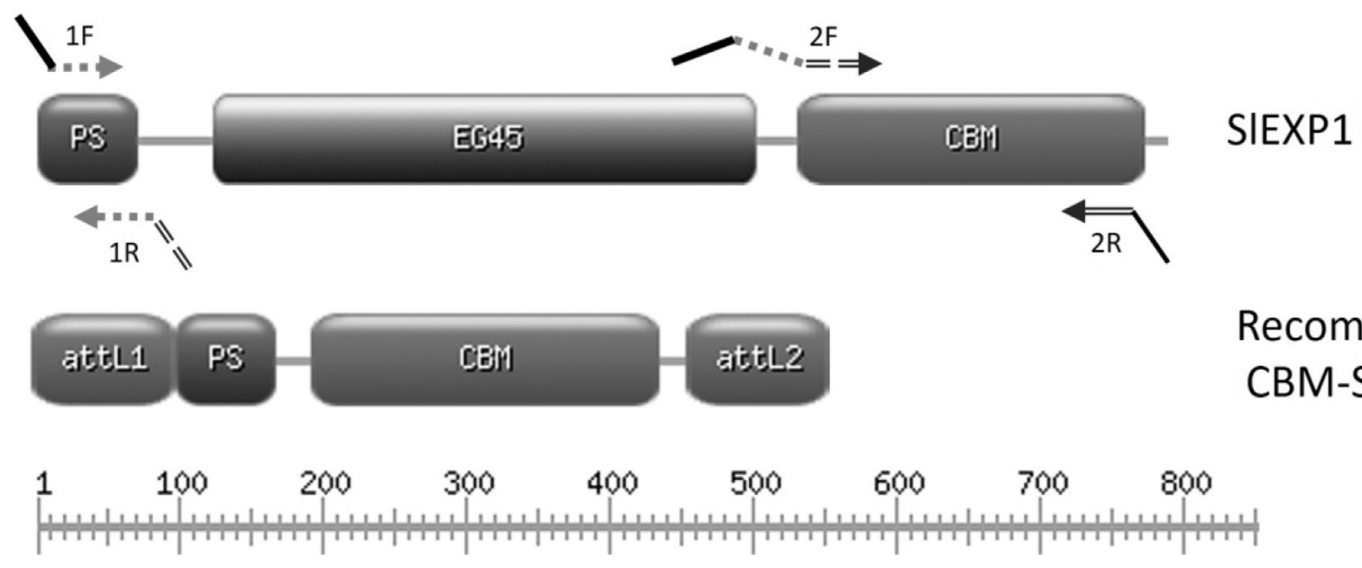

Recombinant
CBM-SIEXP1

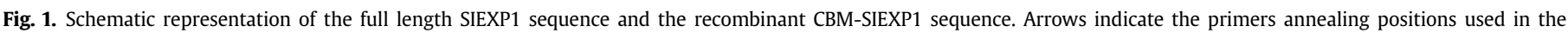

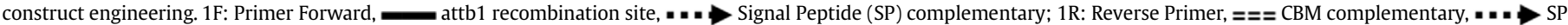

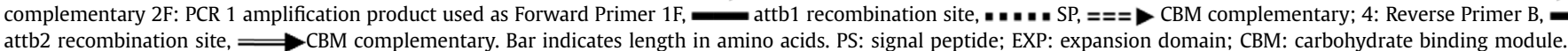




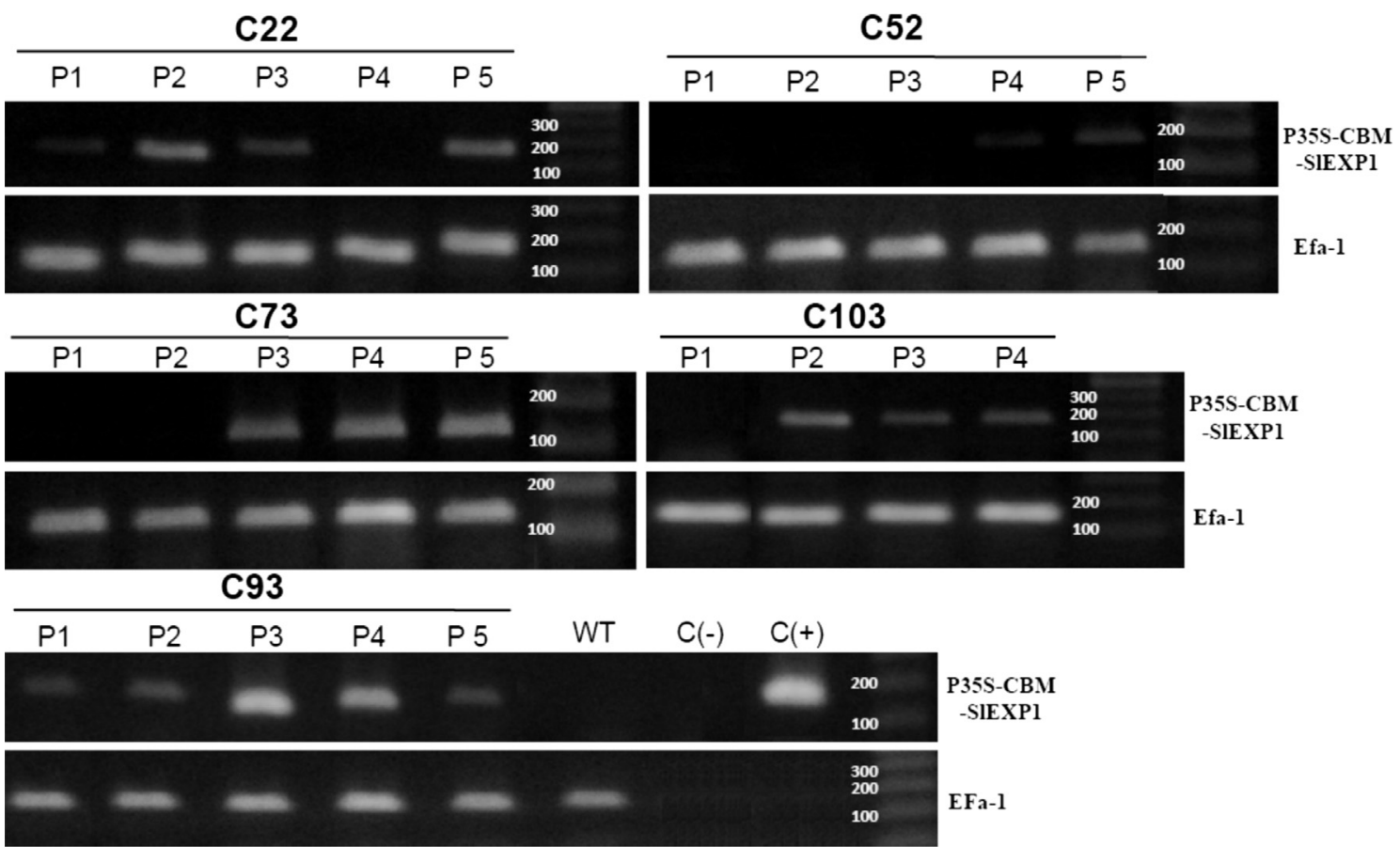

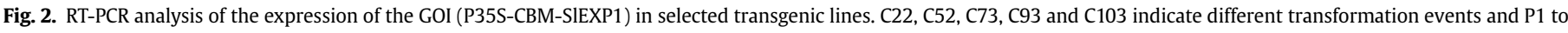

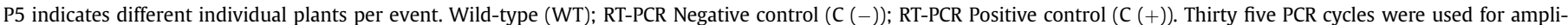
fication of P35S-CBM-Sl-EXP1 and EFa-1 (reference gene).

Table 1

Effect of CBM-Sl-EXP1 overexpression on plant phenotype.

\begin{tabular}{|c|c|c|c|c|c|}
\hline Measurement & & & $\mathrm{WT}^{* 1}$ & Azygous $^{* 2}$ & Transgenic $^{* 3}$ \\
\hline \multirow[t]{7}{*}{$40 \mathrm{~d}$} & Height $(\mathrm{cm})$ & & $74,0 \pm 3,2^{\mathrm{a}}$ & $58,2 \pm 4,2^{b}$ & $60,3 \pm 2,1^{b}$ \\
\hline & $\mathrm{N}^{\circ}$ of flowers & & $7,6 \pm 0,4^{a}$ & $4,0 \pm 1,8^{a}$ & $3,4 \pm 0,9^{a}$ \\
\hline & $\mathrm{N}^{\circ}$ of flower clusters & & $1,0 \pm 0,1^{\mathrm{a}}$ & $0,3 \pm 0,2^{\mathrm{ab}}$ & $0,4 \pm 0,1^{b}$ \\
\hline & SPAD & $4^{\text {ta }}$ leaf & $28,9 \pm 0,9^{\mathrm{ab}}$ & $31,6 \pm 1,5^{\mathrm{bc}}$ & $34,0 \pm 1,0^{c}$ \\
\hline & & $5^{\text {ta }}$ leaf & $35,0 \pm 0,4^{a}$ & $37,9 \pm 0,9^{a}$ & $38,9 \pm 0,9^{a}$ \\
\hline & Area & $4^{\text {ta }}$ leaf & $150,3 \pm 21,9^{a}$ & $152,7 \pm 15,8^{\mathrm{a}}$ & $150,1 \pm 9,9^{a}$ \\
\hline & $\left(\mathrm{cm}^{2}\right)$ & $5^{\text {ta }}$ leaf & $188,8 \pm 25,0^{a}$ & $168,5 \pm 15,4^{\mathrm{a}}$ & $163,4 \pm 11,0^{a}$ \\
\hline \multirow[t]{5}{*}{$60 \mathrm{~d}$} & Height $(\mathrm{cm})$ & & $103,6 \pm 3,7^{\mathrm{a}}$ & $94,2 \pm 5,9^{\mathrm{a}}$ & $99,1 \pm 2,5^{a}$ \\
\hline & $\mathrm{N}^{\circ}$ of flowers & & $23,4 \pm 2,8^{\mathrm{a}}$ & $16,8 \pm 1,5^{\mathrm{a}}$ & $20,8 \pm 1,7^{\mathrm{a}}$ \\
\hline & $\mathrm{N}^{\circ}$ of flower clusters & & $3,0 \pm 0,3^{\mathrm{a}}$ & $2,5 \pm 0,2^{\mathrm{a}}$ & $2,8 \pm 0,2^{\mathrm{a}}$ \\
\hline & SPAD & $4^{\text {ta }}$ leaf & $26,2 \pm 0,6^{\mathrm{a}}$ & $26,9 \pm 1,5^{\mathrm{a}}$ & $26,8 \pm 1,1^{\mathrm{a}}$ \\
\hline & & $5^{\text {ta }}$ leaf & $31,0 \pm 0,7^{a}$ & $31,2 \pm 1,2^{\mathrm{a}}$ & $32,0 \pm 1,2^{\mathrm{a}}$ \\
\hline
\end{tabular}

*1. Data correspond to measurements means \pm SE of five independent plants.

*2. Data correspond to measurements means \pm SE of seven independent plants.

*3. Data correspond to measurements means \pm SE of seventeen independent plants.

Results were analyzed by ANOVA and means were compared by Tukey test at $\mathrm{p}<0.05$. Same letters indicate no statistical difference among plants.

kanamycin and GFP selectable marker genes and a Cauliflower Mosaic Virus promoter (P35S-CaMV) for the constitutive expression of the gene of interest (GOI), the SIEXP1 SP-CBM construct, CBM-SIEXP1.

Eleven independent transformation events were obtained after tissue culture selection and plant regeneration, three of which turned out to be infertile. Fertile transformed plants were grown for two generations, and individual overexpressing and azygous plants were identified by the expression of CBM-SIEXP1 in fruit and used in subsequent assays.

\subsection{CBM-SIEXP1 mRNA expression}

CBM-SIEXP1 mRNA expression in transgenic tomato fruit was confirmed by RT-PCR using a specific set of primers for the GOI.
From 24 plants analyzed, 17 turned out to be positive for the expression of GOI (C22-P1, -P2, -P3, -P5; C52-P4, -P5; C73-P3, -P4, -P5; C93- P1, -P2, -P3, -P4, -P5; C103-P2, -P3 and -P4), and these were labeled as transgenic plants. The other 7 plants (C22-P4; C52$\mathrm{P} 1,-\mathrm{P} 2$; -P3; C73-P1, -P2; C103-P1) were further analyzed using the same set of primers and genomic DNA as template to confirm the absence of the GOI, and were then classified as azygous plants. RTPCR generated a $182 \mathrm{bp}$ amplicon for the GOI and a $110 \mathrm{bp}$ amplicon for the reference gene control (Fig. 2).

In order to assess whether there was an overall effect due to the overexpression of the CBM-SIEXP1 protein, individual plants were classified as transgenic or azygous based on the RT-PCR analysis. This grouping of the plants allowed us to compare the effects of the overexpression of CBM-SIEXP1 using 17 independent transgenic plants (from 5 independent events) and 7 independent azygous 


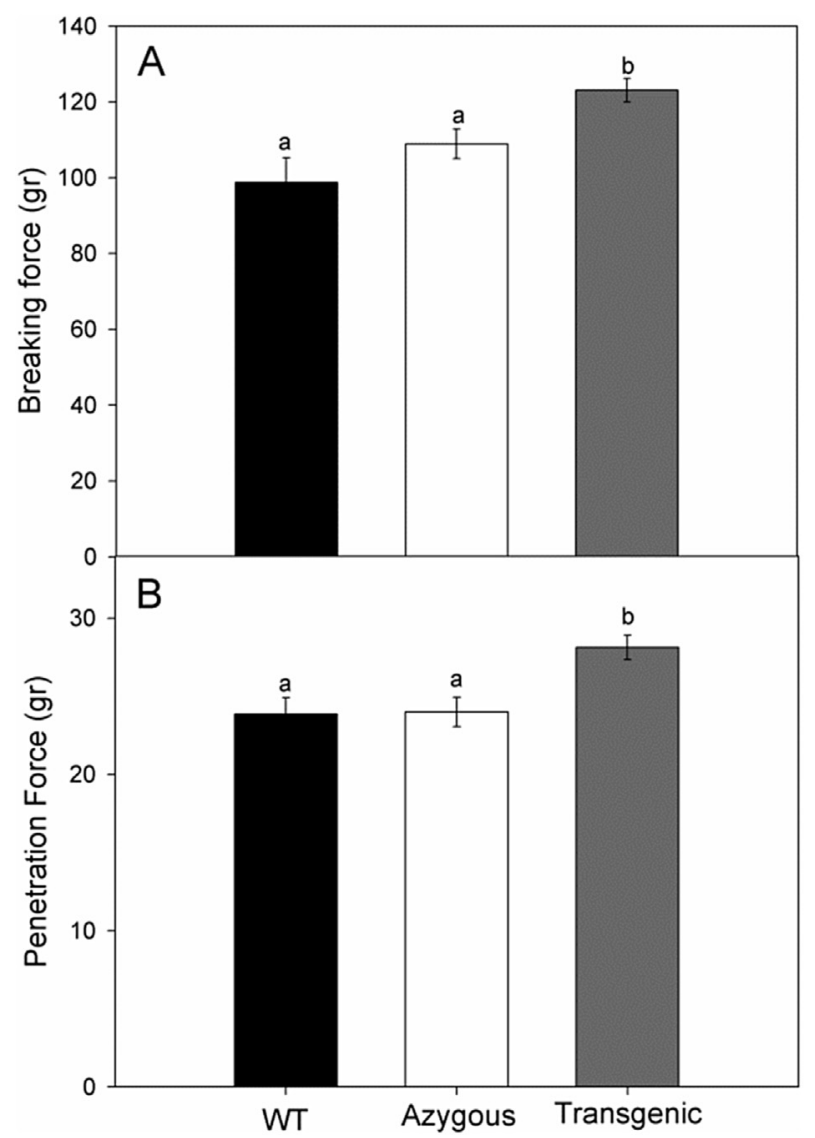

Fig. 3. Mechanical properties of leaves from CBM-SIEXP1 overexpressing plants. A) Breaking force of WT, azygous and transgenic leaves. B) Penetration force of WT, azygous and transgenic leaves. Data correspond to breaking force or penetration force means \pm SE. Results were analyzed by ANOVA and means were compared by Tukey test at $\mathrm{p}<0.05$ of 20 leaves from each plant. Letters indicate significant statistical differences between WT, azygous and transgenic fruit.

plants (from 4 different events). In addition, 5 WT (non-transformed) plants were included as additional controls.

\subsection{Plant phenotypical characterization}

In order to assess the effect of the overexpression of CBM-SIEXP1 on the plant growth and development, phenotypical characteristics were measured and analyzed at two different times (Table 1 ). No statistical significant differences were found between transgenic and azygous plants in plant height, number of flowers or flower clusters at 40 or $60 \mathrm{~d}$ post germination. Fruits developed normally and no visible difference in size was observed (data not shown). However, transgenic plants were shorter and developed fewer flower clusters than the WT at $40 \mathrm{~d}$ post germination, but no differences were observed at $60 \mathrm{~d}$. Regarding the chlorophyll contents (measured in SPAD units on the 4th leaf), leaves from transgenic plants had significantly higher levels of chlorophyll than either azygous and WT plants $40 \mathrm{~d}$ post germination, but no statistical differences were observed in the total foliar area of the same leaves (Table 1).

The mechanical properties of compound leaves were assayed using two complementary measurements. An extension assay measured the force necessary to break sections taken from terminal leaflets. A significantly higher breaking force was found in the case of leaflets from transgenic lines in comparison with the azygous and WT controls (Fig. 3A). Instead, the displacement until breakage was similar for transgenics and the controls (data not shown). The penetration test indicated that the force needed to penetrate the terminal leaflet was significantly higher in the transgenic plants (Fig. 3B).

\subsection{Fruit phenotypical characterization during postharvest storage}

Tomato fruit were harvested at Mature Green stage, and stored at $22{ }^{\circ} \mathrm{C}$ in darkness. Three independent assays were carried out in the same conditions with independent harvests during three different months (June, August and October). Fruit firmness and surface color were used to follow fruit ripening.

All the fruits ripened during postharvest storage. The transgenic fruits reached Breaker stage slightly later $(2-3 \mathrm{~d}$ ) than WT (data not shown). No significant differences were observed in the variation of surface color between the fruit from transgenic, azygous or WT plants (Fig. 4). Instead, the fruits overexpressing the CBM-SIEXP1 were firmer than WT at MG stage and thereafter during storage, even at ripe stage (BR+6 d) (Fig. 4). A similar trend was found when transgenic fruits were compared with azygous control, except for 4 out of 15 cases, where no significant difference was found.

With the aim to identify a possible relationship between the loss of firmness and dehydration during storage, the loss of fruit weight was followed for $14 \mathrm{~d}$. The weight losses increased linearly at similar rates up to $7-8 \%$ during the storage and no statistically significant differences were observed among WT, azygous and transgenic fruit (Fig. 5).

\subsection{Susceptibility to Botrytis cinerea infection and fungal growth on isolated cell wall material}

We analyzed whether the overexpression of CBM-SIEXP1 altered the tomato fruit's susceptibility to infections by $B$. cinerea. Fruit from six transgenic plants and from two controls (WT and azygous) were inoculated in unwounded sites with fungal conidia. Seven days post-inoculation ( $\mathrm{dpi}$ ), neither mature green nor light red fruit showed visible symptoms of infection (data not shown). Nevertheless, lesions were visible from the first day post inoculation for Ripe Red fruit, and visible symptoms were evaluated at 1, 2, 4 and 7 dpi (Table 2). A reduction of the symptoms was observed in Ripe Red fruit from C73-P4, C93-P3 and C103-P3 plants in comparison to WT or azygous fruit (Table 2).

The AIR was extracted from the fruit mesocarp of this set of plants. The amount of AIR was similar in controls (WT and C22-P4 azygous) and transgenic plants except for C93-P3, which had higher amount than controls and the other transgenics (Fig. 7-A).

Growth of $B$. cinerea mycelia on agar plates containing AIRs from transgenic or control fruit (WT and azygous) as the only carbon source was assayed. AIR contained mostly cell wall material and a small amount of starch. A preliminary assay was done to optimize the amount of AIR to be added for pathogen growth (Supp. Fig. 2). An amount of $0.1 \mathrm{mg} \mathrm{mL}^{-1}$ AIR was chosen for further experiments. The presence of small starch amounts in all AIRs was detected in all fruits, but no significant difference was found between fruit from control and transgenic plants (Fig. 7-B). After $24 \mathrm{~h}$, the radial growth of Botrytis on plates containing AIRs from C22-P5, C73-P4, C93-P3, C103-P2 and C103-P3 was lower when compared to azygous lines (Fig. 6). After $72 \mathrm{~h}$ of incubation the pathogen's radial growth was significantly lower in plates containing cell wall AIRs isolated from the transgenic lines as compared to plates containing AIRs from either WT or azygous fruit.

\section{Discussion}

The degradation and remodeling of plant cell walls involve 


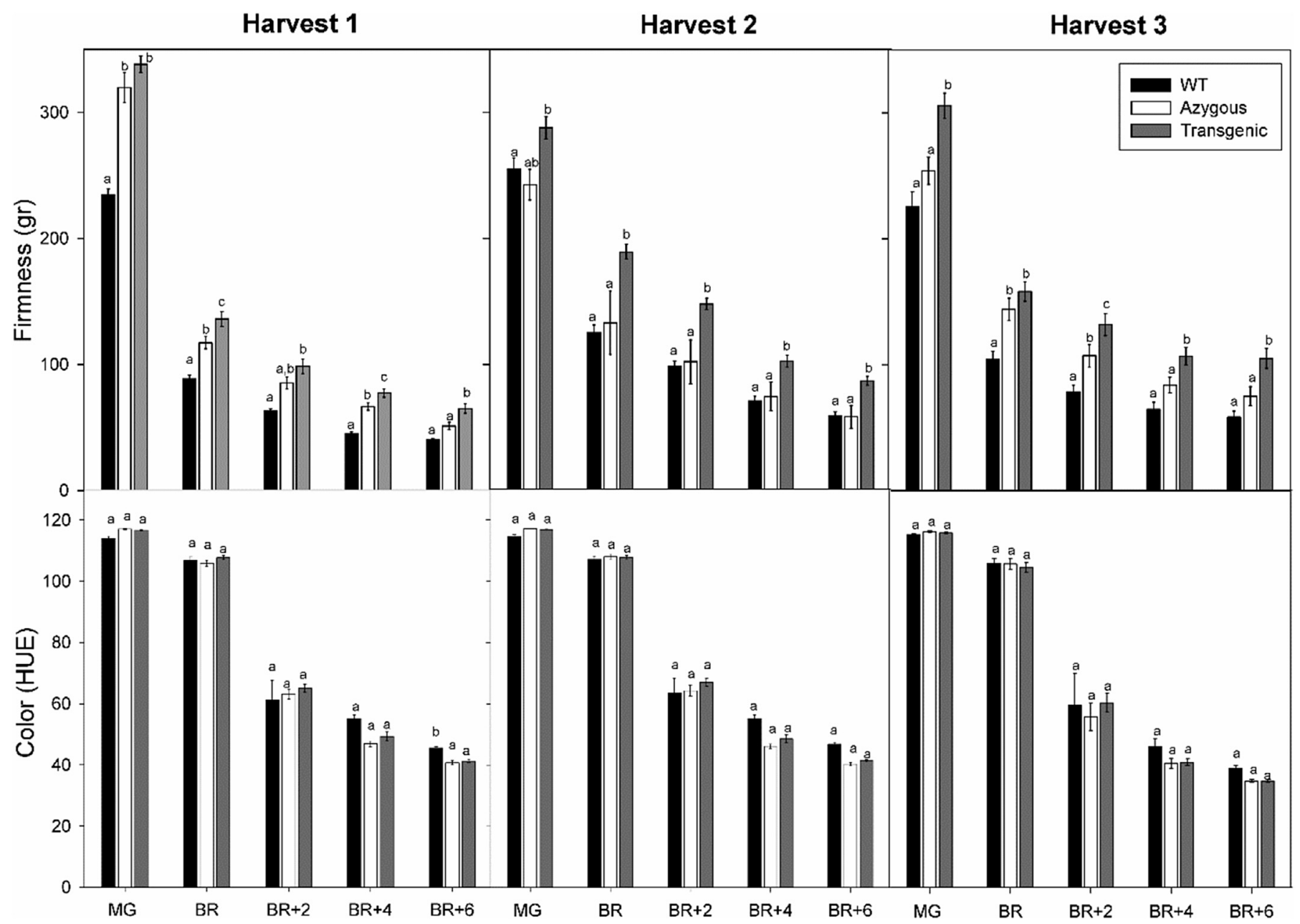

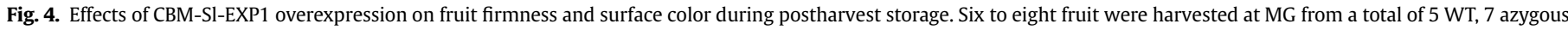

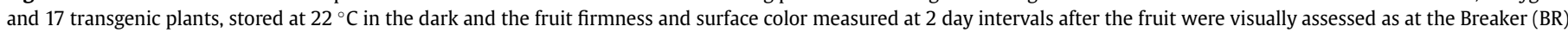

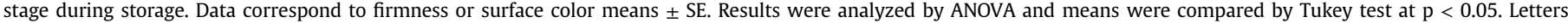
indicate significant statistical differences between WT, azygous and transgenic fruit at the same ripening stage.

multiple enzymes and non-hydrolytic proteins that act on insoluble substrates, and a common feature of many of these enzymes is that they include a catalytic domain and one or more CBM modules (Boraston et al., 2004). Three general roles for CBMs have been proposed: (i) to facilitate the proximity of catalytic domain to the substrate, (ii) to target the catalytic domain to the substrate and (iii) to cause substrate disruption (Arantes and Saddler, 2010; Boraston et al., 2004).

Multiple effects caused by the overexpression of CBMs from different sources on plant phenotypes have been reported (Boron et al., 2015). CBMs from divergent proteins were overexpressed in different plants, such as a bacterial CBM (cellulose-binding-protein A; CBPA) from C. cellulovorans in S. tuberosum (Safra-Dassa et al., 2006); the expansin CBM from S. tuberosum in N. tabacum (Obembe et al., 2007a); the bacterial CBM29 and CBM2b-1-2 in $N$. tabacum (Obembe et al., 2007b) the CBM from strawberry expansin 2 (CBM-FaEXP2) in A. thaliana (Nardi et al., 2015), among others. However, as far as we know, there are no reports on the overexpression of a CBM in fruits and its possible influence on fruit softening. In this work, we overexpressed the CBM from tomato Exp1 (CBM-SIEXP1) in the cell wall of Solanum lycopersicum and analyzed the effects on plant phenotype, fruit ripening and susceptibility to Botrytis cinerea infection.

The election of this particular expansin CBM was based on the relevance of SIEXP1 (previously labeled LeEXP1) gene in tomato fruit softening (Brummell et al., 1999; Rose et al., 1997), the central role of expansins in tomato fruit softening (Brummell and Harpster, 2001), and the binding properties of these proteins to cell wall polysaccharides. The main target of expansin CBMs from different plant and bacterial sources seems to be cellulose, though the capacity to bind to with lower affinity xylans and pectins was also reported (Cosgrove, 2000; Georgelis et al., 2011; Kerff et al., 2008; Nardi et al., 2013).

The phenotype of plants overexpressing CBM-SIEXP1 did not differ substantially from WT during plant growth and development. However, mechanical properties of compound leaves indicated that CBM-SIEXP1 overexpression increased tensile strength of the tissue and resistance to extension and puncture (Fig. 3). Probably, the increase of these parameters in transgenic plants is related to changes in cell wall amount and composition, as it was proved in other plants overexpressing an expansin CBM. The CBM from strawberry expansin 2 (CBM-FaEXP2) was overexpressed constitutively in the cell wall of Arabidopsis thaliana and the leaves from transgenic plants had higher amount of cell walls, which were enriched in pectin (Nardi et al., 2015). Interestingly, the activity of four enzymes related to cell wall metabolism (polygalacturonase, $\beta$ galactosidase, $\beta$-xylosidase and $\alpha$-arabinofuranosidase) was lower in leaves overexpressing CBM-FaEXP2, while the PME activity was 


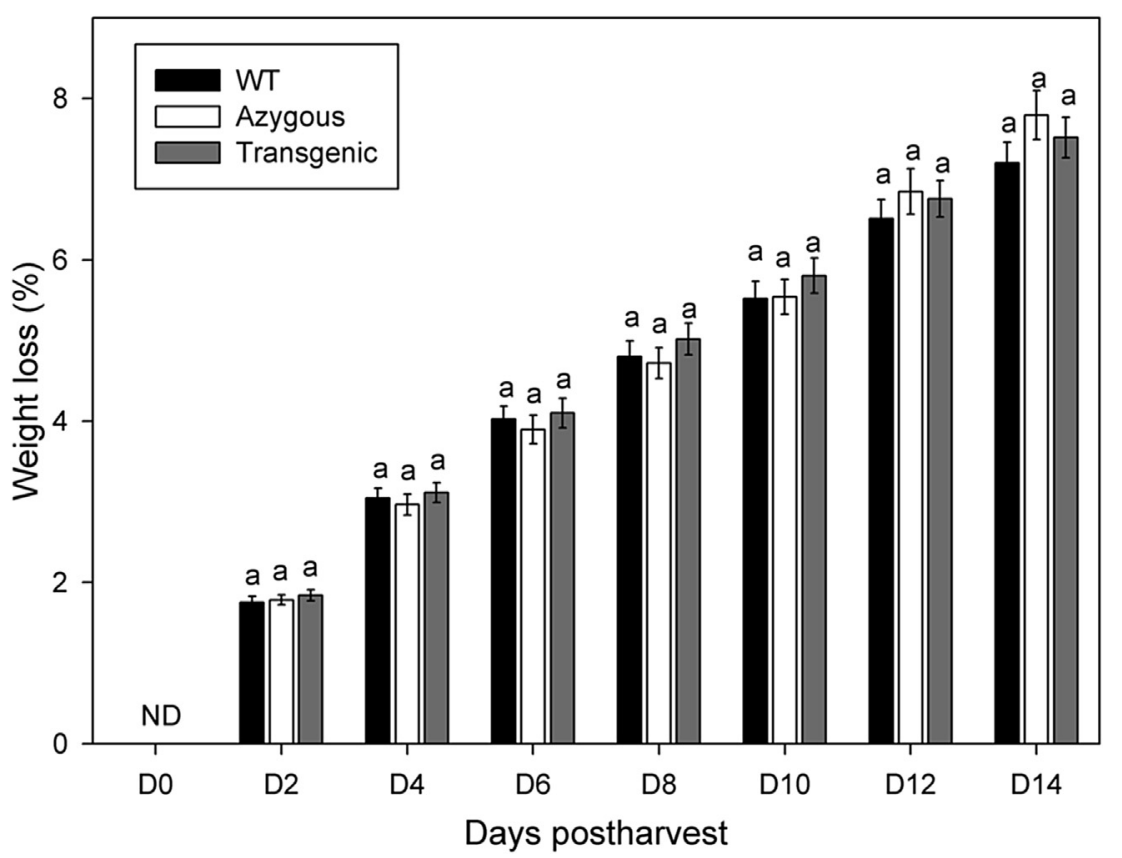

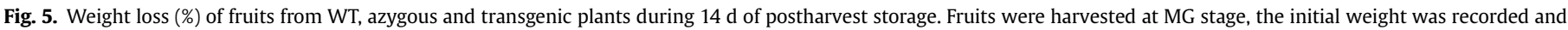

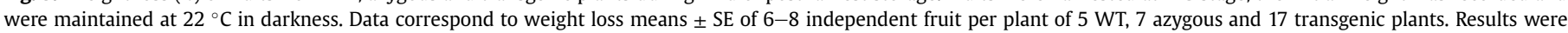
analyzed by ANOVA and means were compared by Tukey test at $\mathrm{p}<0.05$ using WT as control. Letters indicate significant statistical differences.

Table 2

Effect of CBM-Sl-EXP1 overexpression on Botrytis cinerea susceptibility.

Fruit from WT, azygous and transgenic plants at Red Ripe stage were inoculated with B. cinerea conidia and the lesion size was qualitative evaluated.

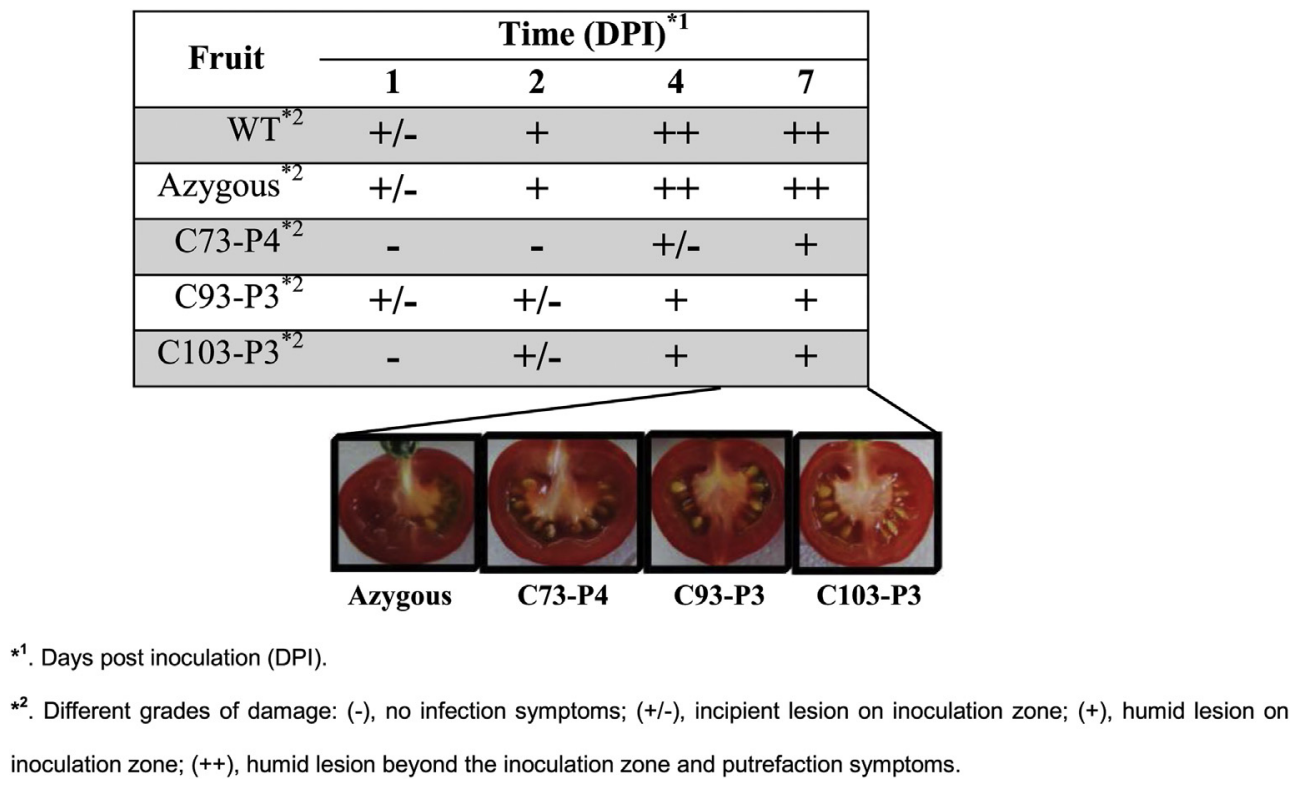

not affected. In addition, the expression of the related genes (AtPG, At $\beta-G a l$, At $\beta-X y l 5$, At $\alpha$-Ara1) was decreased, while the expression of At $\alpha$-PME3 was not affected. In the case of expansins, the expression of two genes (AtExp5 and AtExp8) expressed in rosette leaves was also reduced in transgenic plants (Nardi et al., 2015).

In order to assess whether the overexpression of CBM-SlEXP1 modified fruit quality parameters during storage, fruit were phenotyped during postharvest ripening. Fruit ripening was monitored by color change and weight loss, and no difference was found between the transgenic fruit and the controls. The weight loss values were similar to those reported in tomato stored under similar conditions (Javanmardi and Kubota, 2006). However, the transgenic fruits were firmer than the controls during storage. As no differences in fruit weight were found, the higher firmness of transgenic fruit would not be related to the influence of water loss or fruit turgor. Instead, the overexpression of CBM-SIEXP1 in the cell wall decreases fruit softening probably by affecting cell wall metabolism. The results obtained with a set of plants showed that 




Fig. 6. Growth of $B$. cinerea on plates containing agar $0.8 \%(w / v)$ and $0.1 \mathrm{mg} \mathrm{mL}^{-1}$ of alcohol insoluble residues (AIRs) obtained from Light Red stage fruit of WT, azygous (C22-P4) and transgenic fruit. C22-P2; C22-P5, C73-P4, C93-P3, C103-P2 and C103-P3 represent the six independent transgenic plants selected. Data correspond to $B$. cinerea mycelia growth area means \pm SE of three independent determination. Results were analyzed by ANOVA and means were compared by Tukey test at $p<0.05$. Letters indicate significant statistical differences.

the cell wall amount from fruit mesocarp was similar in all controls and transgenic plants assayed, except by C93-P3, which accumulated more cell wall (Fig. 7-A). All the AIRs contained a small amount of starch, which was similar in all control and transgenic plants analyzed (Fig. 7-B).

Tomato plants engineered for overexpression or suppression of the full length Sl-EXP1 in the cell wall of tomato fruit have been analyzed previously (Brummell et al., 1999). The plants overexpressing the full length SIEXP1 produced smaller fruit, which were softer than fruit from azygous control plants. On the other hand, the suppression of the full length gene did not noticeably modify the plant phenotype or the ripening either, but produced firmer fruits than controls (Brummell et al., 1999). All the plants had similar yield of cell wall material, and no correlation with firmness data were found. However, the suppression of the full length SlEXP1 delayed pectin depolymerization while did not modify hemicelluloses depolymerization in comparison with the controls (Brummell et al., 1999).

More recently, a mutagenized tomato plant population was obtained and screened for plants impaired in SIExp1 function using TILLING approach (Minoia et al., 2015). Two mutants were identified, in which the loss of SlExp1 function caused enhanced fruit firmness and delayed fruit ripening. The Slexp1-7 (Q213Stop) mutant had significant differences in uronic acid, neutral sugar and total sugar contents and their fruit pericarp xyloglucan structures were affected. Interestingly, both mutations that affected fruit softening corresponded to the CBM of Sl-EXP1, while other mutations that involved the putative expansin catalytic domain did not modify fruit softening. Suppression of full length EXP1 (Brummell et al., 1999), the mutation of SIEXP1 at the CBM encoding sequence by TILLING (Minoia et al., 2015), and the overexpression of CBM-SIEXP1 reported in this work are different strategies that share the same gene target, and all of them successfully delayed tomato fruit softening, probably because of the interferences caused on regular expansin activity and cell wall metabolism. In addition, the results obtained with the last two strategies involving the CBM of Sl-EXP1, and the results obtained in A. thaliana with the CBM of FaEXP2, mentioned above, suggest that the contribution of expansin domains on cell wall metabolism could be higher than thought before.

Botrytis cinerea is one of the most studied necrotrophic fungal plant pathogens responsible for the gray mold disease and it is a significant contributor to postharvest decay in fresh fleshy fruits (Shah et al., 2012; van Kan, 2006). We selected fruits from 1 WT, 1 azygous, and 6 transgenic plants to analyze whether overexpression of CBM-SIEXP1 altered the susceptibility of tomato fruit to infections with Botrytis. The infection of fresh fruits with Botrytis conidia indicated that fruit overexpressing CBM-SIEXP1 were less susceptible to develop fungal growth. From another point of view, the "in vitro" culture of Botrytis on media containing the same amount of AIR from control and transgenic plants as only carbon source indicated that the fungus grew less on AIR from transgenic plants. AIRS contained mostly cell wall material, but also a small amount of starch, which was similar in all samples. Therefore, the lower growth of Botrytis on AIRs from the transgenic plants could be due to higher cell wall integrity and not to a differential effect on starch accumulation.

It has been reported that the overexpression of the carbohydrate binding module of strawberry expansin 2 in Arabidopsis thaliana modified cell wall metabolism and caused increased resistance of rosette leaves to B. cinerea infections compared to WT (Nardi et al., 2015). This resistance was correlated with a higher amount and lower degradation of cell wall in CBM-FaEXP2 overexpressing plants. Fruit firmness does not correlate always with the tissue sensitivity against Botrytis infection. In the case of tomato, Brummell et al. (2002) found larger disease lesions in firmer, EXP1suppressed fruit when they were exposed to $B$. cinerea and A. alternata. Otherwise, tomato fruit with simultaneous suppression of Sl-EXP1 and LePG, the ripening-associated polygalacturonase gene, were both firmer and less susceptible to B. cinerea infection than controls (Cantu et al., 2008). The suppression of both gene expression led to a dramatic reduction in depolymerization of pectin fractions, while no alterations of hemicellulosic polymer sugar composition, solubility, or size distribution were observed (Cantu et al., 2008). Even when expansins bind 




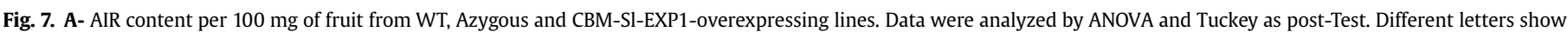

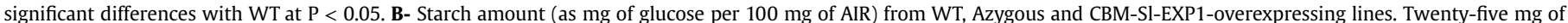

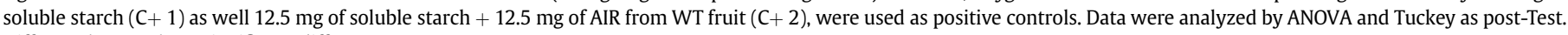
Different letters show significant differences at $\mathrm{P}<0.05$.

strongly to cellulose or xyloglucan-rich Cel-Hem network (Rose and Bennett, 1999), there is growing evidence that expansins have an important role in pectin metabolism during fruit ripening.

\section{Contributions}

Lic. Mauro Perini and Lic. Ignacio Sin performed the cloning of expansin gene in the vectors used for transformation. Once obtained the transgenic plants, they performed the phenotype characterization of plant and fruit. Both of them participated actively of the data analysis, discussion and the manuscript redaction. Both authors contributed equally to this work.

Dra. Natalia Villarreal and Dra. María Marina performed the experiments with Botrytis cinerea, and collaborated with the manuscript redaction.

Dra. Ann Powell participated of plant transformation and selection of first plant generation, experiment design, data analysis, discussion and manuscript redaction.

Dr. Gustavo Martínez and Dr. Marcos Civello directed the research project, designed the experimental approach, and participated actively of data analysis, discussion and the manuscript writing.

\section{Acknowledgements}

This work was supported by Consejo Nacional de Investigaciones Científicas y Técnicas (CONICET; NSF-CONICET Res. $\mathrm{N}^{\circ}$ 597/12), Agencia Nacional de Promoción Científica y Tecnológica (ANPCyT; PICT 2012-0215; PICT 2015-3081) and Universidad Nacional de La Plata (UNLP). Authors thank to Santiago Martínez and María Gabriela Cano (INFIVE; CONICET, Argentina) for their valuable technical assistance.

\section{Appendix A. Supplementary data}

Supplementary data related to this article can be found at http:// dx.doi.org/10.1016/j.plaphy.2017.01.029.

\section{References}

Arantes, V., Saddler, J.N., 2010. Access to cellulose limits the efficiency of enzymatic hydrolysis: the role of amorphogenesis. Biotechnol. Biofuels 3, 1-11.

Boraston, A.B., Bolam, D.N., Gilbert, H.J., Davies, G.J., 2004. Carbohydrate-binding modules: fine-tuning polysaccharide recognition. Biochem. J. 382, 769-781.

Boron, A.K., Van Loock, B., Suslov, D., Markakis, M.N., Verbelen, J.P., Vissenberg, K, 2015. Over-expression of AtEXLA2 alters etiolated arabidopsis hypocotyl growth. Ann. Bot. 115, 67-80.

Brummell, D.A., 2006. Cell wall disassembly in ripening fruit. Funct. Plant Biol. 33, 103-119.

Brummell, D.A., Harpster, M.H., 2001. Cell wall metabolism in fruit softening and quality and its manipulation in transgenic plants. Plant Mol. Biol. 47, 311-340. 
http://dx.doi.org/10.1023/A:1010656104304.

Brummell, D.A., Harpster, M.H., Civello, P.M., Palys, J.M., Bennett, A.B., Dunsmui, P., 1999. Modification of expansin protein abundance in tomato fruit alters softening and cell wall polymer metabolism during ripening. Plant Cell Online 11, 2203-2216. http://dx.doi.org/10.1105/tpc.11.11.2203.

Brummell, D.A., Howie, W.J., Ma, C., Dunsmuir, P., 2002. Postharvest fruit quality of transgenic tomatoes suppressed in expression of a ripening-related expansin. Postharvest Biol. Technol. 25, 209-220. http://dx.doi.org/10.1016/S09255214(01)00179-X.

Cantu, D., Vicente, A.R., Greve, L.C., Dewey, F.M., Bennett, A.B., Labavitch, J.M. Powell, a L.T., 2008. The intersection between cell wall disassembly, ripening, and fruit susceptibility to Botrytis cinerea. Proc. Natl. Acad. Sci. U. S. A. 105, 859-864.

Carpita, N.C., Kanabus, J., 1987. Extraction of starch by dimethyl sulfoxide and quantitation by enzymatic assay. Anal. Biochem. 161, 132-139.

Cosgrove, D.J., 2000. Loosening of plant cell walls by expansins. Nature 407, $321-326$.

Coutinho, P.M., Henrissat, B., 1999. Carbohydrate-active enzymes: an integrated database approach. Recent Adv. Carbohydr. Bioeng. 3-12.

D'Amour, J., Gosselin, C., Arul, J., Castaigne, F., Willemot, C., 1993. Gamma-radiation affects cell wall composition of strawberries. J. Food Sci. 58, 182-185.

Dotto, M.C., Martínez, G. a., Civello, P.M., 2006. Expression of expansin genes in strawberry varieties with contrasting fruit firmness. Plant Physiol. Biochem. 44, 301-307.

Flors, V., Leyva, M.D.L.O., Vicedo, B., Finiti, I., Real, M.D., García-Agustín, P., Bennett, A.B., González-Bosch, C., 2007. Absence of the endo- $\beta$-1,4-glucanases Cel1 and Cel2 reduces susceptibility to Botrytis cinerea in tomato. Plant J. 52, 1027-1040.

Georgelis, N., Tabuchi, A., Nikolaidis, N., Cosgrove, D.J., 2011. Structure-function analysis of the bacterial expansin EXLX1. J. Biol. Chem. 286, 16814-16823.

Harker, F.R., Redgwell, R.J., Hallett, I.C., Murray, S.H., Carter, G., 1997. Texture of fresh fruit. Hortic. Rev. Am. Soc. Hortic. Sci. 20, 121-224.

Harrison, E.P., McQueen-Mason, S.J., Manning, K., 2001. Expression of six expansin genes in relation to extension activity in developing strawberry fruit. J. Exp. Bot. $52,1437-1446$

Hayama, H., Ito, A., Moriguchi, T., Kashimura, Y., 2003. Identification of a new expansin gene closely associated with peach fruit softening. Postharvest Biol. Technol. 29, 1-10.

Hiwasa, K., Rose, J.K.C., Nakano, R., Inaba, A., Kubo, Y., 2003. Differential expression of seven alpha-expansin genes during growth and ripening of pear fruit. Physiol. Plant 117, 564-572.

Javanmardi, J., Kubota, C., 2006. Variation of lycopene, antioxidant activity, total soluble solids and weight loss of tomato during postharvest storage. Postharvest Biol. Technol. 41, 151-155.

Karimi, M., Inzé, D., Depicker, A., 2002. GATEWAYтм vectors for Agrobacteriummediated plant transformation. Trends Plant Sci. 7, 193-195.

Kerff, F., Amoroso, A., Herman, R., Sauvage, E., Petrella, S., Filée, P., Charlier, P., Joris, B., Tabuchi, A., Nikolaidis, N., Cosgrove, D.J., 2008. Crystal structure and activity of Bacillus subtilis YoaJ (EXLX1), a bacterial expansin that promotes root colonization. Proc. Natl. Acad. Sci. U. S. A. 105, 16876-16881.

Lee, Y., Choi, D., Kende, H., 2001. Expansins: ever-expanding numbers and functions. Curr. Opin. Plant Biol. 4, 527-532.

Levy, I., Shoseyov, O., 2002. Cellulose-binding domains: biotechnological applications. Biotechnol. Adv. 20, 191-213.

McQueen-Mason, S., Durachko, D.M., Cosgrove, D.J., 1992. Two endogenous proteins that induce cell wall extension in plants. Plant Cell 4, 1425-1433.

McQueen-Mason, S.J., Cosgrove, D.J., 1995. Expansin mode of action on cell walls, Analysis of wall hydrolysis, stress relaxation, and binding. Plant Physiol. 107, 87-100.

Minoia, S., Boualem, A., Marcel, F., Troadec, C., Quemener, B., Cellini, F., Petrozza, A., Vigouroux, J., Lahaye, M., Carriero, F., Bendahmane, A., 2015. Induced mutations in tomato SIExp1 alter cell wall metabolism and delay fruit softening. Plant Sci.
242, 195-202.

Nardi, C.F., Escudero, C., Villarreal, N.M., Martínez, G. Civello, P.M., 2013. The carbohydrate-binding module of Fragaria $\times$ ananassa expansin 2 (CBM-FaExp2) binds to cell wall polysaccharides and decreases cell wall enzyme activities "in vitro." J. Plant Res. 126, 151-159.

Nardi, C.F., Villarreal, N.M., Rossi, F.R., Martínez, S., Martínez, G. a., Civello, P.M., 2015. Overexpression of the carbohydrate binding module of strawberry expansin2 in Arabidopsis thaliana modifies plant growth and cell wall metabolism. Plant Mol. Biol. 88, 101-117.

Obembe, O.O., Jacobsen, E., Visser, R., Vincken, J.P., 2007a. Expression of an expansin carbohydrate-binding module affects xylem and phloem formation. African J. Biotechnol 6, 1608-1616.

Obembe, O.O., Jacobsen, E., Timmers, J., Gilbert, H., Blake, A.W., Knox, J.P., Visser, R.G.F., Vincken, J.P., 2007b. Promiscuous, non-catalytic, tandem carbohydrate-binding modules modulate the cell-wall structure and development of transgenic tobacco (Nicotiana tabacum) plants. J. Plant Res. 120 605-617.

Petersen, T.N., Brunak, S., von Heijne, G., Nielsen, H., 2011. SignalP 4.0: discriminating signal peptides from transmembrane regions. Nat. Methods 8, 785-786.

Pombo, M.A., Zheng, Y., Fernandez-Pozo, N., Dunham, D.M., Fei, Z., Martin, G.B. 2014. Transcriptomic analysis reveals tomato genes whose expression is induced specifically during effector-triggered immunity and identifies the Epk1 protein kinase which is required for the host response to three bacterial effector proteins. Genome Biol. 15, 492.

Rose, J.K.C., Lee, H.H., Bennett, A.B., 1997. Expression of a divergent expansin gene is fruit-specific and ripening-regulated. Proc. Natl. Acad. Sci. U. S. A. 94 5955-5960.

Rose, J.K.C., Bennett, A.B., 1999. Cooperative disassembly of the cellulose-xyloglucan network of plant cell walls: parallels between cell expansion and fruit ripening. Trends Plant Sci. 4, 176-183.

Safra-Dassa, L., Shani, Z., Danin, A., Roiz, L., Shoseyov, O., Wolf, S., 2006. Growth modulation of transgenic potato plants by heterologous expression of bacteria carbohydrate-binding module. Mol. Breed. 17, 355-364.

Sampedro, J., Carey, R.E., Cosgrove, D.J., 2006. Genome histories clarify evolution of the expansin superfamily: new insights from the poplar genome and pine ESTs. J. Plant Res. 119, 11-21.

Sampedro, J., Cosgrove, D.J., 2005. The expansin superfamily. Genome Biol. 6, 242.

Schneider, C. a, Rasband, W.S., Eliceiri, K.W., 2012. NIH Image to ImageJ: 25 years of image analysis. Nat. Methods 9, 671-675.

Shah, P., Powell, A.L.T., Orlando, R., Bergmann, C., Gutierrez-Sanchez, G., 2012 Proteomic analysis of ripening tomato fruit infected by botrytis cinerea. J. Proteom. Res. 11, 2178-2192.

Shoseyov, O., Shani, Z., Levy, I., 2006. Carbohydrate binding modules: biochemica properties and novel applications. Microbiol. Mol. Biol. Rev. 70, 283-295.

Sievers, F., Wilm, A., Dineen, D., Gibson, T.J., Karplus, K., Li, W., Lopez, R., McWilliam, H., Remmert, M., Söding, J., Thompson, J.D., Higgins, D.G., 2011. Fast scalable generation of high-quality protein multiple sequence alignments using Clustal Omega. Mol. Syst. Biol. 7, 539.

Sigrist, C.J.A., De Castro, E., Cerutti, L., Cuche, B.A., Hulo, N., Bridge, A., Bougueleret, L., Xenarios, I., 2013. New and continuing developments at PROSITE. Nucleic Acids Res. 41, 1-4.

Sin, I.N., Perini, M. a., Martínez, G. a., Civello, P.M., 2016. Analysis of the carbohydrate-binding-module from Fragaria $\mathrm{x}$ ananassa $\alpha$-L-arabinofuranosidase 1. Plant Physiol. Biochem. 107, 96-103.

Taiz, L., Zeiger, E., 2006. Plant Physiology, fourth ed. Sinauer Associates, Sunderland, MA. 764 pages.

van Kan, J.A.L., 2006. Licensed to kill: the lifestyle of a necrotrophic plant pathogen. Trends Plant Sci. 11, 247-253.

Yennawar, N.H., Li, L.-C., Dudzinski, D.M., Tabuchi, A., Cosgrove, D.J., 2006. Crystal structure and activities of EXPB1 (Zea m 1), a beta-expansin and group-1 pollen allergen from maize. Proc. Natl. Acad. Sci. U. S. A. 103, 14664-14671. 